\title{
Temperature Effects on Fruit Development and Quality Performance of Nagami Kumquat (Fortunella margarita [Lour.] Swingle)
}

\author{
Yung-Chiung Chang* and Tian-Cih Lin
}

Department of Horticulture, National Ilan University, No. 1, Sec. 1, Shen-Lung Rd, Ilan 260, Taiwan, ROC

This study was conducted to investigate the effects of different temperature treatments on kumquat fruit development and qualities. Kumquat trees were placed in growth chambers at day/night temperatures of $36^{\circ} \mathrm{C} /$ $28^{\circ} \mathrm{C}, 28^{\circ} \mathrm{C} / 20^{\circ} \mathrm{C}$, and then $20^{\circ} \mathrm{C} / 12^{\circ} \mathrm{C}$ two weeks after the first physiological fruit drop. The results showed that there was a positive correlation between temperature and fruit drop. The total fruit drop rate increased with temperature. The group at $36^{\circ} \mathrm{C} / 28^{\circ} \mathrm{C}$ had the highest total fruit drop rate of $63.7 \%$. High temperature $\left(36^{\circ} \mathrm{C} / 28^{\circ} \mathrm{C}\right)$ suppressed kumquat fruit growth. With increases in temperature, the lengths and diameters of fruits decreased. Moreover, the kumquat peel color in the $36^{\circ} \mathrm{C} / 28^{\circ} \mathrm{C}$ and $28^{\circ} \mathrm{C} / 20^{\circ} \mathrm{C}$ groups did not change from green to orange. High day/night temperatures $\left(36^{\circ} \mathrm{C} / 28^{\circ} \mathrm{C}\right)$ during fruit growth stages suppressed fruit growth and could reduce fruit quality. Low day/night temperatures $\left(20^{\circ} \mathrm{C} / 12^{\circ} \mathrm{C}\right)$ prolonged the fruit development period, increasing fruit size and allowing peel color to change successfully. In order to avoid fruit drop caused by high temperatures at the fruit setting stage, pruning in early February is recommended.

Key Words: defoliation, fruit drop, high temperature, peel color, small citrus.

\section{Introduction}

Kumquat is a subtropical evergreen shrub of the Rutaceae family. It grows quickly and sprouts flushes $3-5$ times per year in regions around $24.5^{\circ}$ north latitude. The buds blossom on mature shoots when the temperature exceeds $25^{\circ} \mathrm{C}$. Following six months of blooming, the fruit becomes mature, with multiple blossoms and multiple fruits (Chang et al., 2014). Unlike other species of citrus plants, the kumquat is a small fruit for whole fruit consumption. The sugar content of kumquat's peel is higher than that of its pulp, but it generally tastes sourer. Therefore, it is traditionally made into processed products such as candied fruits or jams. Recent studies have shown that kumquat fruits are rich in flavonoids and bioactive micronutrients (Barreca et al., 2011; Lou et al., 2016). Moreover, essential oils in the fruit peel have inhibitory effects on the growth of fungi and bacteria (Wang et al., 2012), which is beneficial to human health. Thus, it is a unique type of fruit tree with great potential in Asia.

Cultivation temperature affects fruit growth and shape. When cultivated at $22^{\circ} \mathrm{C}$, the fruit of persimmon

Received; July 27, 2019. Accepted; January 28, 2020.

First Published Online in J-STAGE on May 23, 2020.

* Corresponding author (E-mail: changyc@niu.edu.tw). becomes heavier, and its skin becomes darker. Comparatively, cultivation at $30^{\circ} \mathrm{C}$ delays fruit expansion, and thereby fruit ripening (Sugiura et al., 1991). Passion fruit ripens fastest at $28^{\circ} \mathrm{C} / 23^{\circ} \mathrm{C}$ (day/night) with the largest juice volume; however, fruit weight and juice volume are the lowest at $33^{\circ} \mathrm{C} / 28^{\circ} \mathrm{C}$ (Utsunomiya, 1992). The growth and ripening rate of cherimoya fruits are slower at $30^{\circ} \mathrm{C} / 25^{\circ} \mathrm{C}$ than at $20^{\circ} \mathrm{C} / 15^{\circ} \mathrm{C}$, and the fruit size decreases in environments with higher temperatures (Higuchi et al., 1998). The aspect ratio of pumelo decreases due to increases in daytime temperature (Susanto et al., 1991). In general, the higher the temperature during citrus fruit development, the more vigorous the respiration rate, and more carbohydrate is consumed.

Under high temperatures and drought stresses, plant water imbalances may result in fruit drop (Sato, 2015). The nutrition requirements of citrus trees are higher during flowering and fruiting periods; therefore, trees produce and accumulate most carbohydrate in the growth stage. If nutrient accumulation is insufficient, high temperature may also lead to enhanced respiration and weakened photosynthesis, causing a nutritional imbalance, thereby aggravating the abscission of flowers and fruits (Vu, 1999; Ribeiro et al., 2009). When flowering or early fruit development stages encountered high temperatures, the abscissions of flowers or young 
fruits of citrus trees increased (Randhawa and Dhillon, 1966). High-temperature resulted in an increase in fruit dropping of Washington navel orange (Luo, 1991) and purple passion fruit (Utsunomiya, 1992). Moreover, no matter what the pollinated temperature, fruit growth at relatively higher temperatures increases the fruit dropping rate and reduces the fruit setting rate (Higuchi et al., 1998).

The fruit development temperature affects the sugar/ acidity ratio of citrus fruits (Utsunomiya et al., 1982; Richardson et al., 1997). The peel of citrus fruits is thicker in colder climates, along with an increase in the sugar/acidity ratio; conversely, the sugar/acidity ratio decreases in warmer climates (Chang et al., 1987). When the temperature decreases, starch hydrolysis in plants becomes more vigorous, so the starch content decreases, and the soluble sugar content (primarily glucose and sucrose) increases. Therefore, the sugar content of plants negatively correlates with the growth temperature (Hopkin and Hüner, 2008). Wallwork et al. (1998) indicated that high temperature could lead to a decrease in the activity of amylase synthase and so heat shock may lead to a decrease in sucrose cleavage and starch accumulation (Wang et al., 1993; Lorenzen and Lafta, 1996). The soluble sugar and starch contents of mango fruit are higher at low temperature compared to those at high temperature (Chen and Cheng, 1997). Long-term growth under high temperature leads to greater respiration consumption than photosynthetic accumulation, resulting in exhausted stores of carbohydrates and starved plants (Hopkin and Hüner, 2008). Our previous studies confirmed that the flowering of kumquats was induced when the temperature was above $25 / 18^{\circ} \mathrm{C}$ (Chang et al., 2014). Some studies also reported results about kumquat growth habits. Drought stress was positively correlated with the flowering of Meiwa kumquat (Iwasaki et al., 2000; Ono et al., 2010; Iwasaki and Hiratsuka, 2019). With available water of $35 \%$ for two weeks, the potted Nagami kumquat changed to the shoot growth phase and showed enhanced flowering (Chang et al., 2015). Since there are fewer studies on small fruit citrus than large fruit citrus, the plant characteristics in the subsequent growth stages such as fruit development are still uncertain. The purpose of this study was to determine the effects of different temperatures on the growth, development, and quality of kumquat fruit, in order to improve their yield and fruit quality.

\section{Materials and Methods}

\section{Plant materials}

The tested plants were Nagami kumquat (Fortunella margarita [Lour.] Swingle) that grew for two years after grafting on Poncirus trifoliata (L.) Raf. Plants were planted in plastic pots $(\mathrm{L} \times \mathrm{D} \times \mathrm{H}=45 \times 26 \times$ $23.5 \mathrm{~cm}$ with $8.5 \mathrm{~L}$ of soil volume). The planting medium was a combination in the following proportions: soil:sand:peat moss: coconut fiber $=2: 4: 1: 1$. Thirty-five grams of a 180-day type fertilizer (Hi-Control No. 1 [N:P:K = 14:12:14], JCAM AGRI CO., LTD., Tokyo, Japan) and 30 grams of Jinyu fertilizer (N:P:K: Organic Matter $=4: 1: 1: 77$, Sanyi Inc., Changhua, Taiwan) were applied every three months, and a fertilizer with a dilution rate of 1:1000 (Peter's [N:P:K $=20: 20: 20]$, JR Peters Inc., Allentown, USA) was applied once every two weeks. Pesticides were sprayed once a month, and pesticide use was adjusted according to seasonal pests and diseases. The potted kumquat trees were placed in a plastic greenhouse at National Ilan University, which is located in I-Lan County in northeastern Taiwan $\left(23.5^{\circ} \mathrm{N}, 120.3^{\circ} \mathrm{E}\right)$. Tree shoots were pruned from January to February and all shoots sprouting after July were removed to avoid unnecessary nutrient consumption (Xing et al., 2017).

\section{Experimental design}

The pruned kumquat trees sprouted new shoots in early March, blossomed and fruited at the end of June, and ended their first physiological fruit drop two weeks after fruit set in 2013. On July 14, 2013, trees that had completed physiological fruit drop along with trees of similar vitality were transplanted into a growth chamber (ST4-W3D; SAINT TIEN CO., LTD., Kaohsiung, Taiwan) for subsequent experiments. On December 31, following 170 days of temperature treatment, the fruits and shoots were collected and used for further analysis. In order to avoid drastic environmental changes, the initial temperatures of the growth chambers in each treatment were set at $28^{\circ} \mathrm{C} / 20^{\circ} \mathrm{C}$. From July 15 to July 23 , a gradual temperature adjustment of $1^{\circ} \mathrm{C}$ per day was performed. The final day/night temperature treatments were set at $36^{\circ} \mathrm{C} / 28^{\circ} \mathrm{C}, 28^{\circ} \mathrm{C} / 20^{\circ} \mathrm{C}$, and $20^{\circ} \mathrm{C} / 12^{\circ} \mathrm{C}$, with day/night periods of equal length (i.e., $12 \mathrm{~h}$ ). A randomized complete block design was adopted as the experimental design. Each treatment was repeated four times with one tree each. The light intensity in the growth chamber was $450 \mu \mathrm{mol} \cdot \mathrm{m}^{-2} \cdot \mathrm{s}^{-1}$, which was assessed $20 \mathrm{~cm}$ under the lamp using a photometer (LI-250A \& LI-190; Li-Cor Inc., Lincoln, NE, USA).

\section{Investigation and measurements \\ 1) Leaf area}

The fallen leaf areas of the experimental trees were measured by using an LI-3000 Area Meter (LI-3000 Area Meter; Li-Cor).

2) Fruit growth

The total fruit number per tree was recorded before trees were placed into different chambers, so the number and ratio of fruit drop per tree could be estimated. The fruit lengths and diameters were recorded monthly. 3) Fruit quality

Ripe fruits were harvested in December 2013. The weights of the fruit peel, pulp, peel juice, pulp juice, and seeds were recorded using an electronic scale, and 
the percentages of each were calculated accordingly. The peel and pulp of each fruit were separated and individually homogenized into slush by a juicer. The total soluble solid contents (TSS) of the peel, pulp, and whole fruit were measured by a refractometer (N1- $\alpha$; ATAGO CO., LTD., Tokyo, Japan) and expressed as ${ }^{\circ}$ Brix. The titratable acidity was determined by measurement of peel and pulp as follows: briefly, $25 \mathrm{~mL}$ of puree from peel or pulp was sampled and made up to $250 \mathrm{~mL}$ by adding distilled water. Then, $25 \mathrm{~mL}$ of this sample was titrated against $0.1 \mathrm{~N} \mathrm{NaOH}$ using phenolphthalein as an indicator until a color change was observed. The titration volume $\left(\mathrm{V}_{1}\right)$ was recorded and converted to the percentage of citric acid $\left(\mathrm{V}_{1} \times 0.1 \div\right.$ $25 \mathrm{~mL} \times 0.064 \times 10 \times 100 \%=$ citric acid content [\%]). And the fruit sugar/acidity ratio (TSS/TA ratio) was calculated by dividing the soluble solid content by the titratable acid content (Zhang and Zhou, 2019).

Fruit color was evaluated by a portable colorimeter (Color Guide 45/0; BYK-Gardner, GmbH, Geretsried, Germany) with three parameters of lightness (L), a, and b. Each fruit was measured at three locations, and L represented the color brightness. The hue angle $(H=$ $\tan ^{-1} \mathrm{~b} / \mathrm{a}$ ) was calculated by $\tan ^{-1}(\mathrm{~b} / \mathrm{a})$. The color vector angle was red at 0 degrees, yellow at 90 degrees, and orange at 45 degrees. Chroma represented the color concentration by using the formula $\mathrm{C}=\left(\mathrm{a}^{2}+\mathrm{b}^{2}\right)^{1 / 2}$.

\section{4) Content of total soluble sugar and starch in shoots}

At the end of the temperature treatment, labeled shoots for growth measurements were collected for analysis of total soluble sugar and starch. The determination of total soluble sugar content was performed using a modification of Morris's method (1948). The shoots were dried at $70^{\circ} \mathrm{C}$ and milled into powders of which $1 \mathrm{~g}$ was taken and used for sample analysis. Each sample solution was prepared by adding $50 \mathrm{~mL}$ of $80 \%$ ethanol, followed by water bathing at $80^{\circ} \mathrm{C}$ for 30 minutes, and filtering the solution using filter papers (No. 2, ADVANTEC; Toyo Roshi Kaisha, LTD., Tokyo, Japan). The residues were supplemented with $20 \mathrm{~mL}$ of $80 \%$ ethanol, water-bathed at $80^{\circ} \mathrm{C}$ for 30 minutes and filtered. Each sample repeated the extraction process three times, and three filtrates were collected and mixed for further processing. The filtrate solution with ethanol removed was diluted into a total volume of $100 \mathrm{~mL}$ with polyvinylpyrrolidone. Two $\mathrm{mL}$ diluted solution obtained after the procedure was supplemented with $4 \mathrm{~mL}$ anthrone solution, followed by water bathing at $100^{\circ} \mathrm{C}$ for 6.5 minutes, and rapid cooling in ice water. The absorbance value of the sample solution was measured at $625 \mathrm{~nm}$ wavelength by using a spectrophotometer (Thermo Biomate 3; Thermo Fisher Scientific, Waltham, MA, USA).

The starch content was determined as the residue of the soluble total sugar, which was bathed in water for 30 minutes at $80^{\circ} \mathrm{C}$ for a third time. The residue was filtered and dried with filter paper. Then, $0.5 \mathrm{~g}$ of dried powder was added to $25 \mathrm{~mL}$ of $2 \% \mathrm{HCl}$. After 3.5 hours in a water bath at $90^{\circ} \mathrm{C}$, the filtrate was filtered with filter paper (No.2, ADVANTEC; Toyo Roshi Kaisha). The filtrate was neutralized with $5 \mathrm{M} \mathrm{NaOH}$. By using phthalein as an indicator, the solution was titrated until it turned a light pink color and then diluted to an adequate concentration. After that, $2 \mathrm{~mL}$ of the diluent was taken and evenly mixed with $4 \mathrm{~mL}$ anthrone solution, bathed in boiling water at $100^{\circ} \mathrm{C}$ for 6.5 minutes and rapidly cooled in an ice bath. Then, its absorbance value was measured at a wavelength of $625 \mathrm{~nm}$ by using a spectrophotometer (Thermo Biomate 3; Thermo Fisher Scientific).

\section{Statistical analysis}

Using the SAS 9.4 (SAS Institute, Cary, NC, USA) statistical software, the data were analyzed by ANOVA and Tukey's HSD (honestly significant difference) test, and a level of $5 \%$ was considered significant. The drawing software was SimgaPlot 10.0 (Systat Software, San Jose, CA, USA).

\section{Results}

\section{Fallen leaves, fruit drop, and fruit growth}

When the trees were exposed to high temperatures $\left(36^{\circ} \mathrm{C} / 28^{\circ} \mathrm{C}\right)$, the leaves were significantly defoliated at the initial stage and became even more defoliated one month later. Compared with the high-temperature environment, the low-temperature $\left(20^{\circ} \mathrm{C} / 12^{\circ} \mathrm{C}\right)$ treatment showed a lower number of fallen leaves at the initial stage, but this slowly increased in the later stages and was significantly higher than those observed in the other treatment groups (Fig. 1A). In terms of total defoliation, high temperature $\left(36^{\circ} \mathrm{C} / 28^{\circ} \mathrm{C}\right)$ led to the most defoliation, while low temperature $\left(20^{\circ} \mathrm{C} / 12^{\circ} \mathrm{C}\right)$ also significantly increased the total area of defoliation and tree defoliation at medium temperature $\left(28^{\circ} \mathrm{C} / 20^{\circ} \mathrm{C}\right)$ significantly reduced it (Fig. 1B).

The fruit drop rate of the trees treated at $36^{\circ} \mathrm{C} / 28^{\circ} \mathrm{C}$ was $22.6 \%$ after temperature treatment for one month. Even though the fruit drop rate slowed down two months later, it continued to drop approximately $12.2 \%-15.5 \%$ every month. At the fruit ripening stage, the drop rate of fruit at high temperature rose again to approximately $20 \%$, and the total rate of fruit drop reached $63.7 \%$. The rates of fruit drop for the $28^{\circ} \mathrm{C} /$ $20^{\circ} \mathrm{C}$, and $20^{\circ} \mathrm{C} / 12^{\circ} \mathrm{C}$ groups were significantly lower than that in the high-temperature treatment group, and the rate of fruit drop in every stage of the lowtemperature treatment $\left(20^{\circ} \mathrm{C} / 12^{\circ} \mathrm{C}\right)$ was less than $5 \%$, with a total rate of fruit drop of only $3.9 \%$ (Fig. 2 ).

In the high-temperature environment $\left(36^{\circ} \mathrm{C} / 28^{\circ} \mathrm{C}\right)$, the kumquat fruits grew significantly in the first month; however, after rapid growth for one month, the growth almost stopped and the lengths and diameters of the fruits did not change significantly. The fruits of the $28^{\circ} \mathrm{C} / 20^{\circ} \mathrm{C}$, and $20^{\circ} \mathrm{C} / 12^{\circ} \mathrm{C}$ groups showed visible 

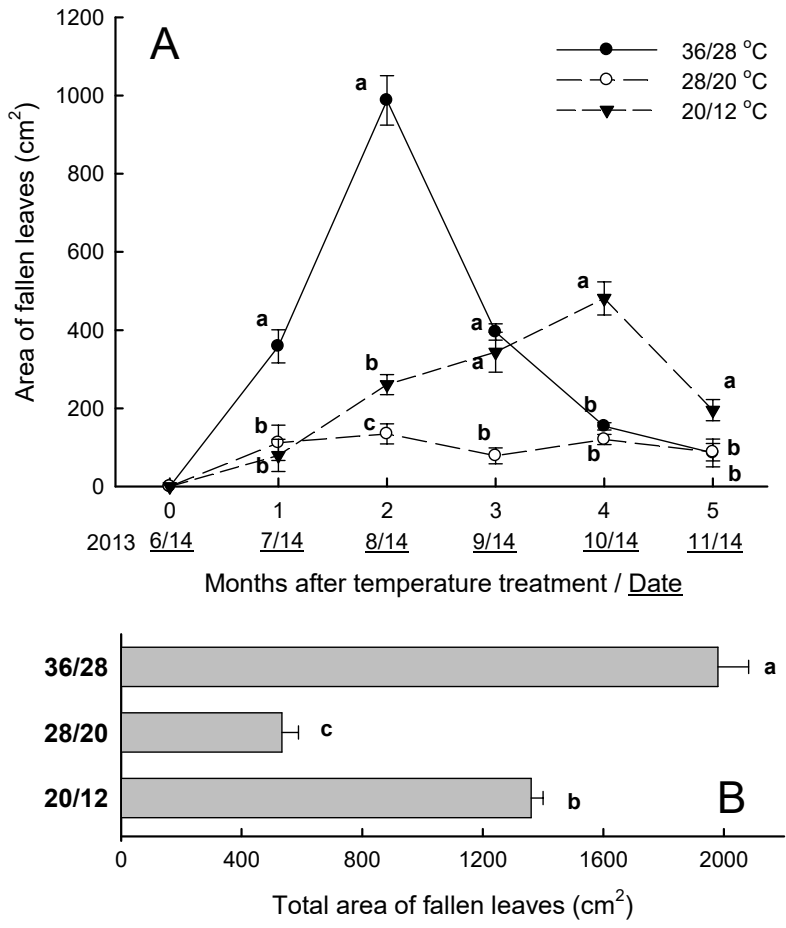

Fig. 1. Effects of day/night temperatures on monthly fallen leaves areas (A) and the total area of fallen leaves (B) of potted Fortunella margarita. Each value represents the mean \pm SE ( $\mathrm{n}$ =4). Means followed by different letters indicate significant differences by Turkey's test $(P<0.05)$. The vertical bars represent standard errors of the averages.
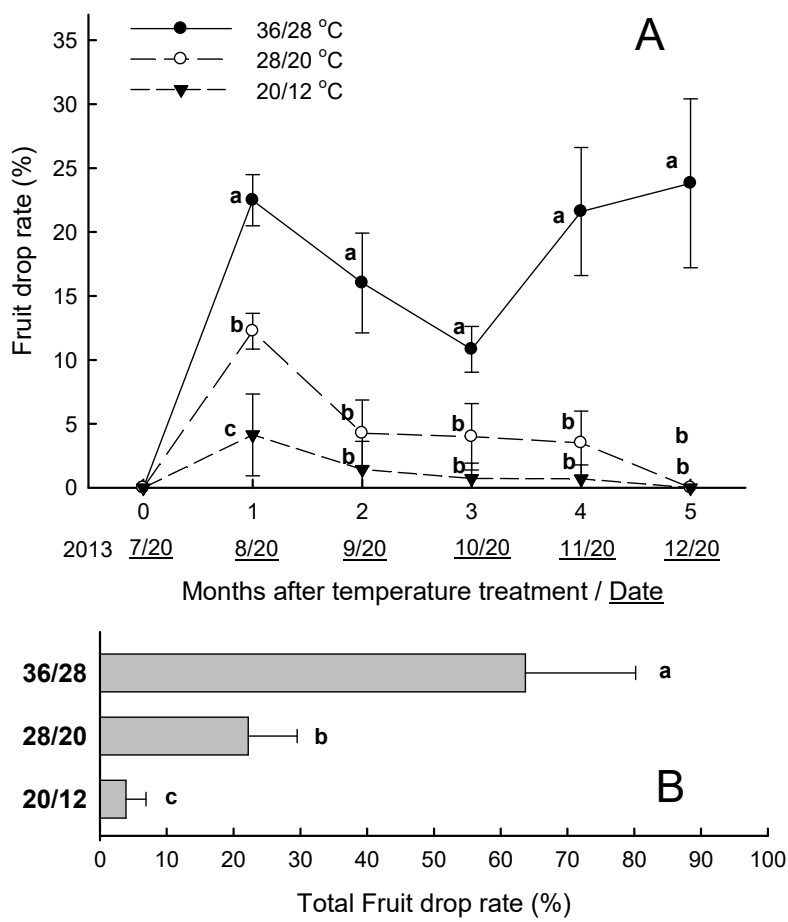

Fig. 2. Effects of day/night temperatures on monthly fruit drop rate (A) and total fruit drop rate (B) of potted Fortunella margarita. Each value represents the mean $\pm \mathrm{SE}(\mathrm{n}=4)$. Means followed by different letters indicate significant differences by Turkey's test $(P<0.05)$. The vertical bars represent standard errors of the averages. changes in their growth, and the lengths and diameters of fruits increased month by month (Fig. 3).

Temperature significantly affected the size and fruit shape of mature kumquat fruits (Table 1). After treatment at different temperatures, the lengths, diameters, and weights of fruits grown in the high-temperature environment $\left(36^{\circ} \mathrm{C} / 28^{\circ} \mathrm{C}\right)$ were significantly lower than those of the other treatment groups, and had no com-

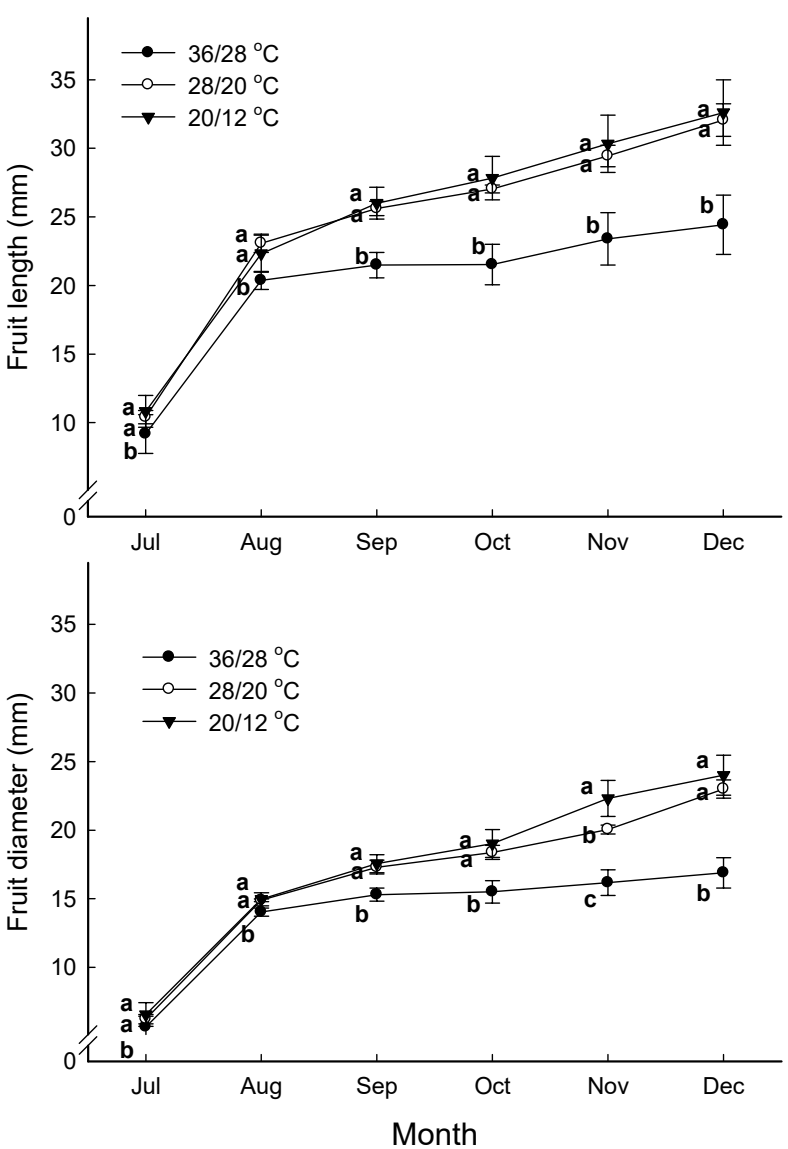

Fig. 3. Effects of day/night temperatures on the fruit length and diameter of potted Fortunella margarita. The data are means of four trees. Each value represents the mean $\pm \operatorname{SE}(n=4)$. Means followed by different letters indicate significant differences by Turkey's test $(P<0.05)$. The vertical bars represent standard errors of the averages.

Table 1. Effects of day/night temperatures on fruit lengths, diameters, shape indexes, and weights of potted Fortunella margarita.

\begin{tabular}{ccccc}
\hline \hline $\begin{array}{c}\text { Day/night } \\
\text { temperature } \\
\left({ }^{\circ} \mathrm{C}\right)\end{array}$ & $\begin{array}{c}\text { Fruit length } \\
(\mathrm{mm})\end{array}$ & $\begin{array}{c}\text { Fruit } \\
\text { diameter } \\
(\mathrm{mm})\end{array}$ & $\begin{array}{c}\text { Fruit shape } \\
\text { index }^{\mathrm{z}}\end{array}$ & $\begin{array}{c}\text { Fruit weight } \\
(\mathrm{g} / \mathrm{p} \text { pr fruit })\end{array}$ \\
\hline $36 / 28$ & $24.4^{\mathrm{y}} \mathrm{b}^{\mathrm{x}}$ & $16.9 \mathrm{~b}$ & $1.45 \mathrm{a}$ & $4.6 \mathrm{c}$ \\
$28 / 20$ & $32.1 \mathrm{a}$ & $23.0 \mathrm{a}$ & $1.39 \mathrm{~b}$ & $10.4 \mathrm{~b}$ \\
$20 / 12$ & $32.6 \mathrm{a}$ & $24.0 \mathrm{a}$ & $1.36 \mathrm{~b}$ & $14.0 \mathrm{a}$ \\
\hline
\end{tabular}

${ }^{\mathrm{z}}$ Fruit shape index $=$ fruit length/fruit diameter.

${ }^{y}$ The data are means of four trees.

${ }^{x}$ Mean values within each column followed by a different letter are significantly different at the $5 \%$ level by Tukey's test. 
mercial value. There was no difference in the lengths and diameters of mature fruits between the treatment groups at $28^{\circ} \mathrm{C} / 20^{\circ} \mathrm{C}$ and $20^{\circ} \mathrm{C} / 12^{\circ} \mathrm{C}$, but the single fruit weight of the treatment group at $20^{\circ} \mathrm{C} / 12^{\circ} \mathrm{C}$ was significantly heavier than that of the treatment group at $28^{\circ} \mathrm{C} / 20^{\circ} \mathrm{C}$. The fruit shape index decreased along with a decrease in treatment temperature. The 1.45 fruit shape index of the treatment group at $36^{\circ} \mathrm{C} / 28^{\circ} \mathrm{C}$ was significantly higher than those of the treatment groups at $28^{\circ} \mathrm{C} / 20^{\circ} \mathrm{C}(1.39)$ and $20^{\circ} \mathrm{C} / 12^{\circ} \mathrm{C}(1.36)$.

The color of kumquat peel also varied with the treatment temperature (Table 2). The color was lightest in the treatment group at $28^{\circ} \mathrm{C} / 20^{\circ} \mathrm{C}(45.0)$, but there was no significant difference among the other treatment groups. The hue angles of the $36^{\circ} \mathrm{C} / 28^{\circ} \mathrm{C}(88.4)$ and $28^{\circ} \mathrm{C} / 20^{\circ} \mathrm{C}$ treatment groups $(92.4)$ were significantly higher than that of the $20^{\circ} \mathrm{C} / 12^{\circ} \mathrm{C}$ treatment group (69.2). The fruits that underwent $36^{\circ} \mathrm{C} / 28^{\circ} \mathrm{C}$ treatment and $28^{\circ} \mathrm{C} / 20^{\circ} \mathrm{C}$ treatment at higher temperature turned out to be yellow-green, whereas those treated at lower temperatures of $20^{\circ} \mathrm{C} / 12^{\circ} \mathrm{C}$ were orange-yellow. The chroma of peel in the $20^{\circ} \mathrm{C} / 12^{\circ} \mathrm{C}$ treatment was significantly higher than those in the other treatment groups (Table 2; Fig. 4).

\section{Fruit quality}

Since kumquat fruits could not mature in the $36^{\circ} \mathrm{C} /$ $28^{\circ} \mathrm{C}$ and $28^{\circ} \mathrm{C} / 20^{\circ} \mathrm{C}$ groups, Table 3 shows data on the quality of mature fruits in the $20^{\circ} \mathrm{C} / 12^{\circ} \mathrm{C}$ group. Unlike large fruit citrus, the proportion of kumquat fruit peel was as high as $29.54 \%$, which was similar to the pulp

Table 2. Effects of day/night temperatures on lightness, hue angle and chroma of peel color of potted Fortunella margarita.

\begin{tabular}{cccc}
\hline \hline $\begin{array}{c}\text { Day/night temperature } \\
\left({ }^{\circ} \mathrm{C}\right)\end{array}$ & Lightness & Hue angle & Chroma \\
\hline $36 / 28$ & $48.0^{\mathrm{z}} \mathrm{a}^{\mathrm{y}}$ & $88.4 \mathrm{a}$ & $40.4 \mathrm{~b}$ \\
$28 / 20$ & $45.0 \mathrm{~b}$ & $92.2 \mathrm{a}$ & $36.6 \mathrm{c}$ \\
$20 / 12$ & $49.7 \mathrm{a}$ & $69.2 \mathrm{~b}$ & $51.1 \mathrm{a}$ \\
\hline
\end{tabular}

$\mathrm{z}$ The data are means of four trees.

${ }^{y}$ Mean values within each column followed by a different letter are significantly different at the $5 \%$ level by Tukey's test.

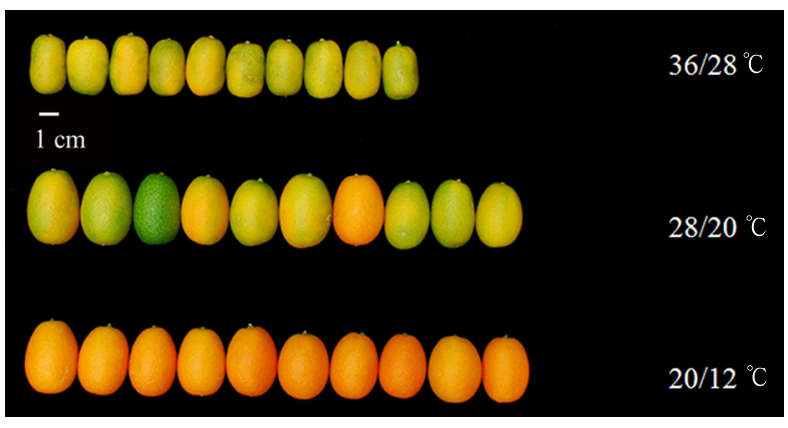

Fig. 4. Effects of day/night temperatures on harvested fruits of potted Fortunella margarita. ratio of $29.62 \%$. The TSS value of the kumquat fruit peel was higher than that of the pulp, but the TA value was lower. Therefore, the TSS/TA ratio of the peel was clearly higher than that of the pulp (Table 3).

\section{Content of total soluble sugar and starch in shoots}

The soluble sugar contents of kumquat shoots displayed significant differences among the treatments (Table 4). With increases in treatment temperature, the shoot soluble sugar contents decreased; the highest value was $21.1 \mathrm{~g} / 100 \mathrm{~g}$ in the $20^{\circ} \mathrm{C} / 12^{\circ} \mathrm{C}$ group, and the lowest was $18.2 \mathrm{~g} / 100 \mathrm{~g}$ in the $36^{\circ} \mathrm{C} / 28^{\circ} \mathrm{C}$ group. The starch content of shoots of $13.5 \mathrm{~g} / 100 \mathrm{~g}$ in the $28^{\circ} \mathrm{C} /$ $20^{\circ} \mathrm{C}$ group, was significantly higher than in the other two groups, and the starch content of shoots in the $36^{\circ} \mathrm{C} / 28^{\circ} \mathrm{C}$ group $(11.6 \mathrm{~g} / 100 \mathrm{~g})$ was significantly lower.

\section{Discussion}

Plants grown at unsuitable temperatures, under drought, or with severe pests and diseases may undergo permanent defoliation due to a drastic reduction in photosynthesis (Hopkin and Hüner, 2008). The hormone content of plants changed significantly under high-temperature stress, and the abscisic acid content increased (Iwahori, 1978), and leaf and fruit abscission were promoted (Hopkin and Hüner, 2008). Under low-

Table 3. The fruit quality of potted Fortunella margarita grown under a day/night temperature of $20 / 12^{\circ} \mathrm{C}$.

\begin{tabular}{|c|c|c|}
\hline Parameter & Fruit part & Content \\
\hline \multirow{5}{*}{ Ratio of fruit (\%) } & Peel & $29.54^{z}$ \\
\hline & Pulp & 29.62 \\
\hline & Peel Juice & 9.58 \\
\hline & Pulp Juice & 27.39 \\
\hline & Seed & 3.88 \\
\hline \multirow{2}{*}{ TSS ( ${ }^{\circ}$ Brix) } & Peel & 14.80 \\
\hline & Pulp & 12.07 \\
\hline \multirow{2}{*}{ TA $(\%)$} & Peel & 1.27 \\
\hline & Pulp & 3.88 \\
\hline \multirow{2}{*}{ TSS/TA ratio } & Peel & 11.73 \\
\hline & Pulp & 3.14 \\
\hline
\end{tabular}

${ }^{\mathrm{z}}$ The data are means of four trees.

Table 4. Effects of day/night temperatures on soluble sugar and starch contents of shoots of potted Fortunella margarita.

\begin{tabular}{ccc}
\hline \hline $\begin{array}{c}\text { Day/night temperature } \\
\left({ }^{\circ} \mathrm{C}\right)\end{array}$ & $\begin{array}{c}\text { Soluble sugar } \\
\text { contents }(\mathrm{g} / 100 \mathrm{~g})\end{array}$ & $\begin{array}{c}\text { Starch contents } \\
(\mathrm{g} / 100 \mathrm{~g})\end{array}$ \\
\hline $36 / 28$ & $18.2^{\mathrm{z}} \mathrm{c}^{\mathrm{y}}$ & $11.6 \mathrm{c}$ \\
$28 / 20$ & $19.4 \mathrm{~b}$ & $13.5 \mathrm{a}$ \\
$20 / 12$ & $21.1 \mathrm{a}$ & $12.4 \mathrm{~b}$ \\
\hline
\end{tabular}

${ }^{z}$ The data are means of four trees.

y Mean values within each column followed by a different letter are significantly different at the $5 \%$ level by Tukey's test. 
temperature stress, plants with more enhanced cold resistance accumulated more abscisic acid than those with weaker cold resistance. Hence, they used abscisic acid to maintain the integrity of the cell membrane to enhance cold resistance (Rubio et al., 2019).

Unsuitable growth temperatures increased kumquat tree defoliation. At a high temperature of $36^{\circ} \mathrm{C} / 28^{\circ} \mathrm{C}$, the trees showed a large amount of leaf shedding from the early stages of treatment, which was similar to the results of the Iwahori study (1978). On the other hand, trees grown at a low temperature of $20^{\circ} \mathrm{C} / 12^{\circ} \mathrm{C}$ showed a continuous increase in leaf falling and peaked in October, probably due to nutrient competition between fruit ripening and the leaf growth.

Citrus that encountered high temperatures during the flowering or fruit development stage developed flower abscissions and fruitlet dropping (Randhawa and Dhillon, 1966). In this study, the fruit drop rate of kumquat trees increased with increasing treatment temperatures. The kumquat trees that grew in an environment of $36^{\circ} \mathrm{C} / 28^{\circ} \mathrm{C}$, showed serious fruit drop; however, the fruit drop clearly decreased with decreasing treatment temperatures. Higuchi et al. (1998) also reported that even if the pollination temperature was high or low, a high-temperature environment increased the rate of fruit drop and reduced the rate of fruit set. In summary, temperatures affect the defoliation and fruit drop of kumquat; there was a positive correlation between temperature and fruit drop (Fig. 5).

The light intensity in the growth chamber was lower than that in the plastic greenhouse. Therefore, when the trees were transferred into the chamber, they expressed physiological tolerance to low-light stress. Kumquat trees had fallen leaves and dropped fruit in the early stage of the experiment in order to reduce photosynthesis accumulation consumption. Moreover, after treatment for three months, the increase in fruit drop in the $20 / 12^{\circ} \mathrm{C}$ group was caused by nutrient competition due

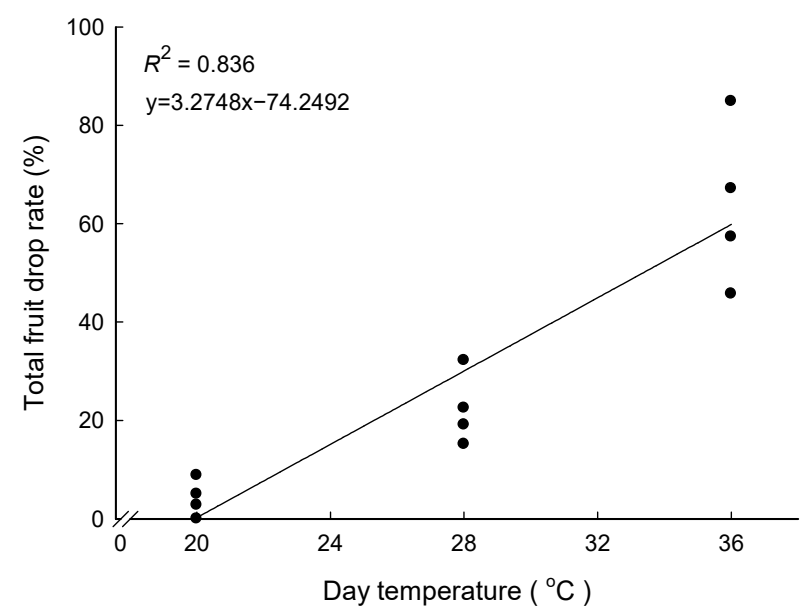

Fig. 5. The correlation between day/night temperatures and total fruit drop rate of potted Fortunella margarita. to the fruit development.

Temperature has a significant influence on the growth and shape of citrus fruits (Susanto and Nakajima, 1990; Richardson et al., 1997). The aspect ratio of Citrus grandis increased with increases in daytime temperature (Susanto et al., 1991). At a high temperature of $36^{\circ} \mathrm{C} / 28^{\circ} \mathrm{C}$, kumquat fruit size increased significantly in both horizontal and vertical directions within one month, and the fruit shape index (fruit length/fruit diameter) was longer and elliptical. This is because whole fruit growth was suppressed at high temperature, and the final fruit was the smallest. Different from the phenomenon of short-term rapid expansion of fruit cells followed by growth termination at high temperature, the growth of kumquat fruits increased with treatment time in both horizontal and vertical directions in the $28^{\circ} \mathrm{C} / 20^{\circ} \mathrm{C}$ and $20^{\circ} \mathrm{C} / 12^{\circ} \mathrm{C}$ groups. The fruit sizes of the $28^{\circ} \mathrm{C} / 20^{\circ} \mathrm{C}$ and $20^{\circ} \mathrm{C} / 12^{\circ} \mathrm{C}$ groups were significantly larger than the $36^{\circ} \mathrm{C} / 28^{\circ} \mathrm{C}$ group, while the fruit sizes of the $28^{\circ} \mathrm{C} / 20^{\circ} \mathrm{C}$ and $20^{\circ} \mathrm{C} / 12^{\circ} \mathrm{C}$ groups were similar. At the end of the experiment, the fruit weight of the $20^{\circ} \mathrm{C} / 12^{\circ} \mathrm{C}$ group was significantly higher than that of the $28^{\circ} \mathrm{C} / 20^{\circ} \mathrm{C}$ group, possibly due to the difference in water and carbohydrate content in the fruit.

During the citrus fruit development stage, the sugar contents and acidity of fruits may vary because of temperature fluctuations (Utsunomiya et al., 1982; Richardson et al., 1997). Citrus fruits have a thicker peel and an increased sugar/acidity ratio when grown in cold climates, whereas the sugar/acidity ratio decreases when they are grown in warm climates (Chang et al., 1987). Concerning Citrus grandis, the fruit acidity was higher at low temperature than that at high temperature (Susanto et al., 1991). The assessment of sugar, acidity, and sugar/acidity ratio of kumquat fruits showed that the acidity of the pericarp was significantly higher at low temperature $\left(20^{\circ} \mathrm{C} / 12^{\circ} \mathrm{C}\right)$. This is similar to the result for passion fruit in which the fruit's acidity increased with decreasing planting temperatures (Utsunomiya, 1992).

Temperature significantly affects the peel color of citrus. The color change in citrus peel is caused by the degradation of chlorophyll and the synthesis of carotenoids. High temperature and humidity may stimulate reversion of chromoplasts to chloroplasts during citrus fruit harvest, resulting in greening of the peel (Tadeo et al., 2008). High temperature $\left(30^{\circ} \mathrm{C}\right)$ inhibited the pigmentation of persimmon, resulting in higher chlorophyll content and lower carotenoid content, allowing the fruits to retain a light green color at maturity (Sugiura et al., 1991). With regards to the hue angles of fruits at different temperature treatments, the fruits of the $36^{\circ} \mathrm{C} / 28^{\circ} \mathrm{C}$ and $28^{\circ} \mathrm{C} / 20^{\circ} \mathrm{C}$ groups tended to be yellow-green, whereas the fruits of the $20^{\circ} \mathrm{C} / 12^{\circ} \mathrm{C}$ and control groups tended to be orange-yellow. However, the fruit treated at $36^{\circ} \mathrm{C} / 28^{\circ} \mathrm{C}$ and $28^{\circ} \mathrm{C} / 20^{\circ} \mathrm{C}$ did not change peel color successfully. Since there was no low 
temperature period during the fruit development stage, the peel chromoplast may have reverted into the chloroplast, followed by peel greening. Alternatively, the higher chlorophyll content and the lower carotenoid content in the peel may have led to the failure of the peel to change color.

When the temperature drops, the starch hydrolytic activity of the plant increases. Accordingly, starch content decreases in winter, while the soluble sugar (mainly glucose and sucrose) content increases; therefore, plant sugar content negatively correlates with the growing temperature (Hopkin and Hüner, 2008). Wallwork et al. (1998) suggested that high temperature would lead to a decrease in the activity of amylase synthase, causing heat shock and leading to a decrease in sucrose cleavage and starch accumulation (Wang et al., 1993; Lorenzen and Lafta, 1996). If plants grow at high temperatures for a long time, their respiration consumption will be higher than photosynthetic assimilation. This may cause carbohydrate accumulated in plants to become gradually exhausted, bringing about starvation and even death (Hopkin and Hüner, 2008).

The results of different temperature treatments showed that the shoot soluble sugars of trees bearing mature fruits were at higher levels than those of the fruitless mature trees (Table 4). The shoot soluble sugars of the $20^{\circ} \mathrm{C} / 21^{\circ} \mathrm{C}$ group was higher than that of the high-temperature groups since the hydrolysis of starch into sugar is more vigorous at low temperature; therefore, the soluble sugar (mainly glucose and sucrose) content inevitably increases. Comparatively, the shoot soluble sugar content in the $36^{\circ} \mathrm{C} / 28^{\circ} \mathrm{C}$ group was the lowest, possibly due to heat shock resulting in sucrose cleavage and reduced starch accumulation. The difference in starch content between different temperatures and treatments showed that overly high and overly low temperatures tended to reduce starch contents. In our previous study, results showed that removing half the length of the shoot from the branches in early February extended the shoot growth period and made the shoot length and diameter longer and wider. If the pruning time was later than June, the ripe fruit ratio of kumquat trees significant decreased because of insufficient shoot growth (Xing et al., 2017). Therefore, even if the tree shoots grow well and bloom and fruit normally, suitable low temperature is necessary during the fruit growth period to ensure that the kumquat fruit matures and the peel color changes from green to orange.

\section{Conclusions}

High temperature $\left(36^{\circ} \mathrm{C} / 28^{\circ} \mathrm{C}\right)$ suppresses kumquat fruit growth and increases leaf falling and fruit dropping; therefore, fruit weight and fruit size decrease, and the color of the fruit peel cannot change from green to orange. Low temperature $\left(20^{\circ} \mathrm{C} / 12^{\circ} \mathrm{C}\right)$ could prolong the fruit development period, increase the fruit size, and make the fruit color change successfully. In order to avoid fruit drop caused by high temperature $\left(>28^{\circ} \mathrm{C}\right)$ at the fruit setting stage, pruning in early February is recommended. Additionally, the initial flowering of kumquat trees starting in May can avoid hightemperature exposure during the fruit developmental stage, which could result in fruit dropping and fruit growth inhibition, and inevitably lead to a decline in final fruit quality.

\section{Literature Cited}

Barreca, D., E. Bellocco, C. Caristi, U. Leuzzi and G. Gattuso. 2011. Kumquat (Fortunella japonica Swingle) juice: Flavonoid distribution and antioxidant properties. Food Research International 44: 2190-2197.

Chang, S. S., F. S. Lee and W. L. Wu. 1987. Influence of temperature and precipitation on fruit quality and leaf nutrients content of Ponkan (Citrus reticulata, Blanco) from major ponkan production areas in Taiwan. J. Agric. Research China 36: 75-86.

Chang, Y. C., Y. S. Chang and L. H. Lin. 2015. Response of shoot growth, photosynthetic capacity, flowering, and fruiting of potted 'Nagami' kumquat to different regulated deficit irrigation. Hortic. Environ. Biotechnol. 56: 444-454.

Chang, Y. C., I. Z. Chen, L. H. Lin and Y. S. Chang. 2014. Temperature effects on shoot growth and flowering of kumquat trees. Kor. J. Hort. Sci. Technol. 32: 1-9.

Chen, I. Z. and C. Y. Cheng. 1997. Effects of air and root temperatures on flowering and leaf carbohydrate and mineral nutrient content of 'Irwin' mango (Mangifera indica L.). J. Chinese Soc. Hort. Sci. 43: 237-248.

Higuchi, H., N. Utsunomiya and T. Sakuratani. 1998. High temperature effects on cherimoya fruit set, growth and development under greenhouse conditions. Sci. Hortic. 77: 23-31.

Hopkin, E. G. and N. P. A. Hüner. 2008. Responses of plants to environmental stress. Ch 13 in "Introduction to Plant Physiology”, $4^{\text {th }}$ ed., pp. 223-240. John Wiley \& Sons, Inc. U.S.A.

Iwahori, S. 1978. Use of growth regulators in the control of cropping of mandarin varieties. Proc. Intl. Soc. Citriculture: 263 270.

Iwasaki, N. and S. Hiratsuka. 2019. Effect of trunk size on the relationship between drought stress and first-flush flower number in Meiwa kumquat. Environ. Control Biol. 57: 1-7.

Iwasaki, N., K. Hayasaki and S. Tanaka. 2000. Effect of water stress on flowering of 'Meiwa' kumquat tree. Environ. Control Biol. 38: 105-109 (In Japanese with English abstract).

Lorenzen, J. H. and A. M. Lafta. 1996. Effect of heat stress on enzymes that affect sucrose levels in potato shoots. J. Am. Soc. Hortic. Sci. 121: 1153-1156.

Lou, S. N., Y. C. Lai, Y. S. Hsu and C. T. Ho. 2016. Phenolic content, antioxidant activity and effective compounds of kumquat extracted by different solvents. Food Chem. 197: $1-6$.

Luo, S. X. 1991. Studies on physiology of flowering and fruit drop of Washington navel orange. Master's thesis, National Taiwan University, pp. 85.

Morris, D. L. 1948. Quantitative determination of carbohydrates with Dreywood's anthrone reagent. Science 107: 254-255.

Ono, T., H. Hagiwara and N. Iwasaki. 2010. Effects of water stress on leaf water potential, flowering, carbohydrate content and ABA content in 'Meiwa' kumquat trees. Hort. Res. (Japan) 9: 209-213 (In Japanese with English abstract).

Randhawa, G. S. and B. S. Dhillon. 1966. Studies on fruit set and 
fruit drop in citrus I. A review. Indian J. Hortic. 22: 33-45.

Ribeiro, R. V., E. C. Machado, M. G. Santos and R. F. Oliveira. 2009. Seasonal and diurnal changes in photosynthetic limitation of young sweet orange trees. Environ. Exp. Bot. 66: 203-211.

Richardson, A. C., K. B. Marsh and E. A. Macrae. 1997. Temperature effects on satsuma mandarin fruit development. J. Hortic. Sci. 72: 919-929.

Rubio, S., X. Noriega and F. J. Pérez. 2019. Abscisic acid (ABA) and low temperatures synergistically increase the expression of CBF/DREB1 transcription factors and cold-hardiness in grapevine dormant buds. Ann. Bot. 123: 681-689.

Sato, K. 2015. Influence of drought and high temperature on citrus. pp. 77-86. In: Y. Kanayama and A. Kochetov (eds.). Abiotic Stress Biology in Horticultural Plants, Springer, Tokyo.

Sugiura, A., G. H. Zheng and K. Yonemori. 1991. Growth and ripening of persimmon fruit at controlled temperatures during growth stage III. HortScience 26: 574-576.

Susanto, S. and Y. Nakajima. 1990. Effect of winter heating on flowering time, fruiting and fruit development in pummelo grown under plastic house. J. Japan. Soc. Hort. Sci. 59: 245253.

Susanto, S., Y. Nakajima and K. Hasegawa. 1991. Effect of different day temperatures of flowering and fruiting in tosa buntan pummelo (Citrus grandis (L). Osbeck). Environ. Control Biol. 29: 97-106.

Tadeo, F. R., M. Cercos, J. M. Colmenero-Flores, D. J. Iglesias, M. A. Naranjo, G. Rios, E. Carrera, O. Ruiz-Rivero, I. Lliso, R. Morillon, P. Ollitrault and M. Talon. 2008. Molecular physiology of development and quality of citrus. Adv. Bot.
Res. 47: 147-223.

Utsunomiya, N. 1992. Effect of temperature on shoot growth, flowering and fruit growth of purple passionfruit (Passiflora edulis Sims var. edulis). Sci. Hortic. 52: 63-68.

Utsunomiya, N., H. Yamada, I. Kataoka and T. Tomana. 1982. The effect of fruit temperatures on the maturation of satsuma mandarin (Citrus unshiu Marc.) fruits. J. Japan. Soc. Hort. Sci. 51: 135-141 (In Japanese with English abstract).

Vu, J. C. V. 1999. Photosynthetic responses of citrus to environmental changes. pp. 947-961. In: M. Pessarakli (ed.). Handbook of Plant and Crop Stress, Marcel Dekker, New York.

Wallwork, M. A. B., S. J. Logue, L. C. MacLeod and C. F. Jenner. 1998. Effect of high temperature during grain filling on starch synthesis in the developing barley grain. Aust. J. Plant Physiol. 25: 173-181.

Wang, F., A. Sanz, M. L. Brenner and A. Smith. 1993. Sucrose synthase, starch accumulation, and tomato fruit sink strength. Plant Physiol. 101: 321-327.

Wang, Y. W., W. C. Zeng, P. Y. Xu, Y. J. Lan, R. X. Zhu, K. Zhong, Y. N. Huang and H. Gao. 2012. Chemical composition and antimicrobial activity of the essential oil of kumquat (Fortunella crassifolia Swingle) peel. Int. J. Mol. Sci. 13: 3382-3393.

Xing, P. H., L. H. Lin and Y. C. Chang. 2017. Studies of pruning on growth and flowering of kumquat (Fortunella margarita (Lour.) Swingle). Ilan Univ. J. Bioresources 13: 65-79.

Zhang, P. and Z. Zhou. 2019. Postharvest ethephon degreening improves fruit color, flavor quality and increases antioxidant capacity in 'Eureka' lemon (Citrus limon (L.) Burm. f.). Sci. Hortic. 248: 70-80. 